\title{
EVALUASI PENYELENGGARAAN LATIHAN UJIAN NASIONAL BAHASA INGGRIS SMA SWASTA EX-RSBI
}

\author{
${ }^{1)}$ Widya Noviana Noor, ${ }^{2)}$ Aman \\ ${ }^{1)}$ IAIN Samarinda, ${ }^{2)}$ Universitas Negeri Yogyakarta \\ ${ }^{2)}$ noviana.widya@ymail.com, ${ }^{2}$ aman@uny.ac.id
}

\begin{abstract}
Abstrak
Penelitian ini bertujuan (1) memperoleh informasi input (antecedents) tentang penyelenggaraan latihan UN, (2) mengetahui proses (transactions) penyelenggaraan latihan UN, dan (3) mengetahui hasil (outcomes) penyelenggaraan latihan UN Mata Pelajaran Bahasa Inggris. Model evaluasi yang digunakan model Stake's. Subjek yang digunakan (1) Dinas Pendidikan Kota Yogyakarta; (2) SMA Swasta ex-RSBI kelas XII di kota Yogyakarta. Teknik pengambilan sampel secara simple random sampling. Sumber data adalah Dinas Pendidikan Kota Yogyakarta, kepala sekolah, dan siswa. Hasil penelitian adalah (1) input (antecedents) penyelenggaraan latihan UN sudah baik dilihat dari dimensi persiapan penyelenggaraannya; (2) proses (transaction) penyelenggaraan latihan UN Mata Pelajaran Bahasa Inggris baik; (3) pada hasil (outcomes) menunjukkan analisis kualitas butir soal baik, terlihat dari tingkat kesukaran butir sedang $(50 \%)$, daya beda baik (70\%), distraktor berfungsi dengan baik (58\%) dan reliabilitas butir termasuk tinggi $(0,851)$. Latihan UN memberikan manfaat cukup baik dan tidak terdapat hambatan dalam penyelenggaraan latihan UN Mata Pelajaran Bahasa Inggris.
\end{abstract}

Kata kunci: tryout, model Stake's (antecedents, transactions dan outcomes), Bahasa Inggris.

\section{AN EVALUATION OF THE IMPLEMENTATION OF ENGLISH NATIONAL EXAMINATION EXERCISE AT EX-RSBI PRIVATE SMA}

\author{
${ }^{1)}$ Widya Noviana Noor, ${ }^{2)}$ Aman \\ ${ }^{1)}$ IAIN Samarinda, ${ }^{2)}$ Universitas Negeri Yogyakarta \\ ${ }^{2)}$ noviana.widya@ymail.com, ${ }^{2}$ aman@uny.ac.id
}

\begin{abstract}
This study aims to (1) obtain the information of the input (antecedents) of English tryout (2) document the process (transactions) of the implementation, and (3) determine the results (outcomes) of the implementation of English tryout. Evaluation model that is used is the Stake's model. The subjects in this research are (1) the Education Office of Yogyakarta; (2) the students of Ex RSBI Private SMA in Yogyakarta. The technique of selecting sampling was by stratified random sampling. The sources of the data at the Regency level is the Education Office of Yogyakarta, principals, and students. The results are (1) the input of the implementation is good if it is viewed from the dimensions of the preparation that include the orientation of question writing, committee, schedule and supervision; (2) process is good if it is viewed from the dimensions of the implementation that included security matter, objectivity of the implementation, and students' perceptions; (3) results show that question items are good. It can be seen from the difficulty of each question that is in medium (50\%), good different power $(70 \%)$, the distractor is functioning properly $(58 \%)$ and reliability in the bigh category (0.851). English tryout gives good benefits and there are no obstacles in the implementation of English tryout.
\end{abstract}

Keywords: tryout, Stake's model (antecedents, transactions and outcomes), English 


\section{Pendahuluan}

Undang-Undang RI Nomor $20 \mathrm{Ta}$ hun 2003 tentang Sistem Pendidikan Nasional Pasal 3 menyebutkan bahwa:

Pendidikan nasional berfungsi mengembangkan kemampuan dan membentuk watak serta peradaban bangsa yang bermartabat dalam rangka mencerdaskan kehidupan bangsa, bertujuan untuk berkembangnya potensi peserta didik agar menjadi manusia yang beriman dan bertakwa kepada Tuban Yang Maha Esa, berakblak mulia, sehat, berilmu, cakap, kreatif, mandiri, dan menjadi warga negara yang demokratis serta bertanggung jawab.

Pembentukan watak menjadi sangat penting, karena hanya orang-orang yang berkepribadian kuat, yang berkarakter, akan lebih tangguh menghadapi globalisasi ataupun dampak-dampak negatifnya. UndangUndang Nomor 20 Tahun 2003 tentang Sistem Pendidikan Nasional (UUSPN 20/ 2003) pasal 50 ayat 3 menyebutkan bahwa "Pemerintah dan/atau Pemerintah Daerah menyelenggarakan sekurang-kurangnya satu satuan pendidikan pada semua jenjang pendidikan untuk dikembangkan menjadi satuan pendidikan yang bertaraf internasional".

Peraturan tersebut melatarbelakangi pemerintah untuk menyelenggarakan Rintisan Sekolah Bertaraf Internasional (RSBI) dengan dilatar belakangi alasan-alasan sebagai berikut: Pertama, era globalisasi menuntut kemampuan daya saing yang kuat dalam teknologi, manajemen dan sumber daya manusia. Kedua, rintisan penyelenggaraan ex-SBI memiliki dasar hukum yang kuat yaitu pasal 50 ayat 3 Undang-Undang Nomor 20 Tahun 2003 tentang Sistem Pendidikan Nasional (UUSPN 20/2003). Ketiga, penyelenggaraan Sekolah Bertaraf Internasional (SBI) didasarkan oleh empat pilar pendidikan yaitu learning to know (belajar mengetahui), learning to do (belajar melakukan), learning to live together (belajar untuk hidup bersama), dan learning to be (belajar untuk menjadi) yang digunakan UNESCO.
Pelaksanaan pembelajaran Bahasa Inggris menggunakan pendekatan awal English as Foreign Language mengingat latar belakang dan masyarakat tempat anak berada tidak menggunakan Bahasa Inggris sebagai bahasa sehari-hari. Pembelajaran Bahasa Inggris dapat disajikan dalam bentuk English as Second Language. Sekolah Berstandar Internasional atau SBI menerapkan pembelajaran Bahasa Inggris sebagai titik perhatian utama. Secara berjenjang tujuan pembelajaran Bahasa Inggris pada tingkat SD/MI, SMP/MTs dan SMA/MA dibedakan untuk mencapai tujuan akhir English as second Language.

Pendidikan merupakan salah satu sarana peningkatan kualitas hidup manusia. Lembaga pendidikan formal, seperti sekolah, memegang peran penting dalam proses pendidikan. Guru-guru sebagai tenaga pendidik juga berperan menyediakan dan memberikan fasilitas untuk memudahkan dan melancarkan cara belajar siswa. Guru harus dapat menciptakan kegiatan-kegiatan yang membantu siswa dalam meningkatkan cara dan hasil belajarnya.

Sekolah sebagai salah satu lembaga pendidikan formal merupakan satu kesatuan sistem dengan lingkungan alam, sosial, budaya, masyarakat dan dunia usaha atau lapangan kerja dimana sekolah berada. Oleh karena itu, dalam perencanaan, pengelolaan dan pelaksanaan pendidikan harus berorientasi pada lingkungan hidup yang selalu berubah. salah satu jenis sekolah yang di harapkan mampu memenuhi kebutuhan tenaga kerja tingkat menengah adalah Sekolah Menengah Atas (SMA). SMA sebagai bentuk bagian pendidikan yang ditegaskan dalam penjelasan pasal 15 Undang-Undang Nomor 20 Tahun 2003 tentang Sistem Pendidikan Nasional (UU SISDIKNAS), merupakan pendidikan menengah yang mempersiapkan peserta didik terutama untuk bekerja dalam bidang tertentu.

Kemerosotan pendidikan sudah terasakan selama bertahun-tahun, untuk kesekian kalinya kurikulum dituding sebagai penyebabnya. Hal ini tercermin dengan adanya upaya mengubah kurikulum mulai kuriku- 
lum 1975 diganti dengan Kurikulum 1984, kemudian diganti lagi dengan Kurikulum 1994 dan sekarang menjadi Kurikulum 2013. Profesionalisme guru dan tenaga kependidikan masih belum memadai utamanya dalam hal bidang keilmuannya. Misalnya guru Biologi dapat mengajar Kimia atau Fisika. Ataupun guru IPS dapat mengajar Bahasa Inggris.

Salah satu penunjang untuk peningkatan mutu pendidikan di Indonesia adalah bahasa. Bahasa memiliki peran sentral dalam perkembangan intelektual, sosial, dan emosional peserta didik dan merupakan penunjang keberhasilan dalam mempelajari semua bidang studi. Pembelajaran bahasa diharapkan membantu peserta didik mengenal dirinya, budayanya, dan budaya orang lain. Selain itu, pembelajaran bahasa juga membantu peserta didik mampu mengemukakan gagasan dan perasaan, berpartisipasi dalam masyarakat, dan bahkan menemukan serta menggunakan kemampuan analitis dan imaginatif yang ada dalam dirinya.

Berbicara tentang bahasa, berarti berbicara tentang alat komunikasi. Bahasa Inggris adalah suatu bahasa yang sangat penting dalam dunia internasional khususnya di era globalisasi sekarang ini. Bahasa Inggris merupakan alat untuk berkomunikasi secara lisan dan tulis. Berkomunikasi adalah memahami, mengungkapkan informasi, pikiran, perasaan, mengembangkan ilmu pengetahuan, teknologi, dan budaya. Kemampuan berkomunikasi dalam pengertian yang utuh adalah kemampuan berwacana, yakni kemampuan memahami, menghasilkan teks lisan atau tulis yang direalisasikan dalam empat keterampilan berbahasa, yaitu mendengarkan, berbicara, membaca dan menulis. Keempat keterampilan inilah yang digunakan untuk menanggapi atau menciptakan wacana dalam kehidupan bermasyarakat.

Leighton and Gierl (2011, pp.9-11) menyatakan bahwa:

"The learning science are an inter-disciplinary domain of study. The five basic facts about learning are the following: (1) Deep conceptual understanding is needed to apply knowledge, (2) learning, not just teaching, must be focus,
(3) learning environment must be created, (4) knowledge builds on itself, and (5) reflection".

Berdasarkan pernyatakan tersebut dapat di simpulkan bahwa ilmu pembelajaran merupakan ilmu interdisiplin yang dalam menerapkan pembelajaran atau pengetahuan ada hal-hal mendasar yang diperlukan antara lain, pemahaman konsep yang mendalam diperlukan dalam pembelajaran, belajar harus fokus membangun pengetahuan untuk diri sendiri.

Pembelajaran Bahasa Inggris di SMA/MA diharapkan dapat mencapai tingkat informational karena mereka disiapkan untuk melanjutkan pendidikannya ke perguruan tinggi. Tingkat literasi epistemic dianggap terlalu tinggi untuk dapat dicapai oleh peserta didik SMA/MA karena Bahasa Inggris di Indonesia berfungsi sebagai bahasa asing.

Mata Pelajaran Bahasa Inggris merupakan salah satu Mata Pelajaran yang kurang diminati siswa. Hal ini terlihat dari banyak siswa yang mengutarakan bahwa Mata Pelajaran Bahasa Inggris cukup sulit jika dibandingkan dengan mata pelajaran lainnya. Kesulitan ini disebabkan karena berbagai faktor antara lain faktor intern yaitu dari diri siswa sendiri yang kurang mampu memahami sepenuhnya terhadap pelajaran bahasa Inggris itu sendiri ditambah faktor minat siswa sendiri juga kurang, bakat siswa, serta perhatian siswa terhadap mata pelajaran. Faktor ekstern adalah faktor guru yang memberikan pelajaran tidak seutuhnya berupaya untuk memberikan pemahaman kepada siswa disebabkan karena kesiapan, metode dan banyak faktor lain yang menyebabkan kesulitan siswa mempelajari bahasa Inggris. Faktor eksternal lainnya adalah alat peraga yang digunakan, metode mengajar guru, relasi guru dengan siswa serta keadaan ekonomi siswa. Baik faktor internal maupun faktor eksternal sedikit banyaknya dapat mempengaruhi terhadap kesulitan belajar siswa yang dapat ditandai dengan banyaknya siswa mengalami kesalahan dalam menyelesaikan soalsoal. 
Di dalam pembelajaran bahasa ada penunjang untuk meningkatkan prestasi siswa dalam berbahasa, yaitu pembelajaran kooperatif seperti yang dikemukakan oleh Reyes, Sharon (2010, pp.92-93).

In the cooperative learning, groups of students works together to accomplish a common task. This can be accomplished through a variety of strategies, descritions of which are readly available in many teacher texts and trade books. Because of rich opportunities provided for smaal group verbal interaction, cooperative learning is especially helpful for student.

Pelajaran Bahasa Inggris adalah mata pelajaran inti yang dipelajari oleh semua jenjang pendidikan di Indonesia, formal atau informal mulai dari Sekolah Dasar (SD) sampai Peguruan Tinggi. Bahasa Inggris telah menjadi suatu alat yang sangat menentukan bagi kelanjutan pendidikan, pekerjaan serta status sosial masyarakat.

Selama ini upaya untuk mengevaluasi hasil belajar Bahasa Inggris berupa evaluasi belajar tahap akhir nasional (EBTANAS), ujian akhir nasional (UAN), dan ujian nasional (UN) telah dilaksanakan. Pendidikan sebagai hak asasi manusia yang diamanatkan dalam Undang-Undang Dasar Republik Indonesia tahun 1945 memang menjadi tanggung jawab dan tugas struktur dominan dalam pembangunannya. Pemerintah berkewajiban meningkatkan mutu pendidikan, yang indikator utamanya adalah pencapaian prestasi siswa. Dilihat dari Undang-Undang Nomor 20 Tahun 2003 tentang Sistem Pendidikan Nasional, terutama pasal 57, 58 dan 59 sebagai upaya peningkatan kualitas hasil pendidikan yang makin merata di seluruh Indonesia adalah melalui ujian nasional. (UU Sisdiknas Nomor 46 Tahun 2010 pasal 1)

Marvin (2011, p.10) menyatakan bahwa "A definition of evaluation based on its goal. Evaluation is the favored term when we talk of judging a program". Makna tersebut diartikan bahwa evaluasi adalah kegiatan untuk mengumpulkan informasi tentang bekerjanya sesuatu, yang selanjutnya informasi tersebut digunakan untuk menentukan alternatif yang tepat dalam mengambil keputusan. Evaluasi adalah sebagai suatu kegiatan yang terencana untuk mengetahui keadaan suatu objek dengan menggunakan instrumen dan hasilnya dibandingkan dengan suatu tolak ukur untuk memperoleh suatu kesimpulan dan hasilnya dipergunakan untuk mengambil keputusan mengenai objek evaluasi.

Model evaluasi yang akan digunakan dalam penelitian Evaluasi Penyelengaraan Latihan UN Mata Pelajaran Bahasa Inggris SMA Swasta ex-RSBI di kota Yogyakarta adalah model Stake, dengan pengertian bahwa model stake adalah model evaluasi yang dikembangkan oleh Stake yang menurut Arikunto dan Jabar (2009, p.43), dalam setiap program yang dievaluasi, evaluator harus mampu mengidentifikasi tiga hal, Antecedent, yang diartikan sebagai masukan, Transaction, yang diartikan sebagai proses, dan Outcome, yang diartikan sebagai hasil.

Dalam model ini, antecedent (input), transaction (proses), dan outcomes (hasil) data dibandingkan tidak hanya untuk menentukan apakah ada perbedaan tujuan dengan keadaan sebenarnya, tetapi juga dibandingkan dengan standar yang absolut, untuk menilai manfaat program. Model Stake ini terkonsentrasi pada dua langkah pekerjaan evaluasi yaitu deskripsi dan pertimbangan.

Model Stake sebenarnya agak mirip dengan model CIPP, namun Stake memasukkan dimensi lain yaitu dimensi deskripsi (Kauffman \& Thomas, 1980, p.123). Stake menekankan adanya pelaksanaan dua hal pokok yaitu: deskripsi (description), pertimbangan (judgment), serta membedakan adanya tiga tahap dalam evaluasi program yaitu: input (antecedent), proses (transaction), dan hasil (outcomes).

Berdasarkan penjelasan tersebut perlu diadakan tes latihan ujian nasional (tryout) untuk memperoleh hasil yang maksimal dalam menghadapi ujian nasional. Tes tryout itu dapat didefinisikan sebagai wahana latihan ujian siswa, baik itu untuk menghadapi ujian semester maupun ujian nasional. Sebenarnya tes tryout itu sudah merupakan suatu kegiatan rutin yang dilaksanakan baik itu oleh kelas 7, 8, 9, 10, 11 maupun 12. Tes merupakan salah satu alat untuk melakukan 
pengukuran, yaitu alat untuk mengumpulkan informasi karakteristik suatu objek (Widoyoko, 2013, p.45). Dengan demikian diperoleh informasi-informasi yang diperlukan. Lebih lanjut, (Mardapi, 2012, p.108) menyatakan bahwa alat yang dapat digunakan dalam melakukan evaluasi, salah satunya adalah tes.

Dalam evaluasi pendidikan diperlukan suatu alat (instrumen) alat tersebut digunakan untuk mengukur aspek-aspek yang terkait dengan pendidikan. Reynolds, Livingston, \& Wilson (2010, p.3) menyatakan bahwa "a test is a divice or preceduer in which a sample of an individual's behavior is obtained, evaluated, and scored using standarized procedures". Pengertian tersebut dapat diartikan, tes adalah sebuah alat atau prosedur di mana sebuah sampel dari prilaku individu diperoleh, dievaluasi, dan diskor dengan menggunakan prosedur yang telah distandarkan. Hoover (2002, p.5) “.......An explanation for gender differences in scores on college admissions exams. It also discusses the roles of norms in achievements batteries and the use of standardized tests in the primary grades". Kesimpulan yang dapat diambil dari pendapat tersebut adalah bahwa tes merupakan alat ukur yang tepat untuk mengukur prestasi dan keberhasilan belajar. Dengan demikian, alat ukur tersebut haruslah memenuhi kriteria-kriteria yang ditetapkan antara lain bahwa alat tes tersebut haruslah valid dan reliabel.

Metode evaluasi yang digunakan terkadang tidak dapat mengetahui sejauh mana pemahaman siswa terhadap mata pelajaran yang diajarkan. Hal ini menimbulkan pertanyaan, apakah tes yang diberikan oleh guru benar-benar mengevaluasi hasil pelajaran? Mengapa siswa yang tergolong cerdas dan rajin nilainya bisa buruk, sedangkan yang tergolong malas nilainya baik? Apakah cara mengajar guru soal yang dibuat atau cara mengevaluasi yang salah? Hal-hal tersebut seharusnya diperhatikan oleh guru, karena cara evaluasi yang salah tentu akan mempengaruhi mutu pendidikan. Evaluasi yang dilakukan dengan baik dan benar dapat meningkatkan mutu dan hasil belajar karena kegiatan evaluasi itu dapat membantu guru memperbaiki cara mengajar dan membantu siswa dalam meningkatkan cara belajarnya agar memperoleh hasil yang maksimal. Oleh karena itu, sebagai calon tenaga pendidik prinsip-prinsip, teknik, dan metode evaluasi proses dan hasil pembelajaran harus benarbenar diketahui untuk di terapkan dalam proses belajar mengajar.

Terkait dengan hal tersebut, penelitian ini bertujuan untuk: (1) memperoleh informasi input (antecedents) tentang penyelenggaraan latihan UN; (2) mengetahui proses (transactions) penyelenggaraan latihan UN, dan (3) mengetahui hasil (outcomes) penyelenggaraan latihan UN Mata Pelajaran Bahasa Inggris.

\section{Metode Penelitian}

Penelitian ini termasuk jenis penelitian evaluatif. Penelitian evaluasi merupakan pengumpulan sistematis informasi tentang aktifitas dan hasil dari program-program aktual untuk menjadi bahan pertimbangan bagi yang berkepentingan terhadap aspekaspek khusus tentang apa yang dilakukan oleh program tersebut dan apa pengaruhnya. Jenis yang dipakai adalah Countenance Stake yang meliputi evaluasi Antecedents, Transactions, dan Outcome.

Penelitian ini dilaksanakan di Dinas Pendidikan Kota Yogyakarta dan SMA Swasta Ex-RSBI di kota Yogyakarta. Waktu pelaksanaan dan penyelesaiannya yaitu bulan Maret sampai dengan Mei 2014.

Subjek dalam penelitian adalah Kepala Bidang Kurikulum Pendidikan Menengah, Dinas Pendidikan Kota Yogyakarta selaku penyelenggara Latihan UN, Panitia penyelenggara latihan UN SMA Swasta exRSBI di kota Yogyakarta yang mengetahui berbagai kebijakan pelaksanaan latihan ujian nasional dan membuat latihan-latihan soal ujian nasional, SMA Swasta ex-RSBI Kota Yogyakarta dan siswa-siswi kelas XII SMA Swasta ex-RSBI di kota Yogyakarta dari masing-masing sekolah yang telah diseleksi dengan cara simple random sampling.

Teknik pengumpulan data yang digunakan untuk memperoleh data yang diperlukan menggunakan teknik wawancara, 
observasi, dan document study. Pengumpulan data merupakan hal yang sangat penting dalam suatu penelitian evaluasi, bertujuan untuk mendapatkan data yang diperlukan, untuk memperoleh informasi yang relevan dengan tujuan penelitian evaluasi. Teknik wawancara dan observasi yang digunakan berpedoman pada teknik yang dikemukakan yaitu diawali dengan observasi dan wawancara.

Teknik analisis data dalam penelitian ini menggunakan teknik analisis statistik deskriptif, yaitu dengan mendeskripsikan dan memaknai data dari setiap variabel yang dievaluasi. Data yang diperoleh dengan teknik kuesioner dianalisis dengan teknik analisis deskriptif kuantitatif. Data dikumpulkan dan dianalisis untuk dideskripsikan berdasarkan sebaran data mean ideal, simpangan baku ideal, dan kategorisasi. Tahapan analisis yaitu: penskoran jawaban responden; penjumlahan skor total tiap-tiap komponen; pengelompokan skor yang dicapai, dan mengolah skor yang didapat oleh responden berdasarkan keterkaitan antar variabel.

Sebelum dianalisis, dilakukan proses kuantifikasi data dari angket, selanjutnya data tersebut dianalisis dengan menggunakan statistik deskriptif melalui program SPSS. Instrumen menggunakan tipe skala likert dengan empat alternatif jawaban, sehingga skor maksimum ideal diperoleh apabila semua butir pada komponen tersebut mendapat skor 4 dan skor minimum ideal diperoleh apabila semua butir pada komponen tersebut mendapat skor 1. Keseluruhan skor yang diperoleh disubstitusikan kedalam tingkat kecenderungan yang dipakai sebagai kriteria evaluasi.

\section{Hasil Penelitian dan Pembahasan}

Data Antecedent (Input)

Berdasarkan hasil penelitian menunjukkan bahwa dari data input (antecedents) secara keseluruhan persiapan penyelenggaraan latihan ujian nasional sudah sesuai. Berdasarkan Surat Keputusan Kepala Dinas Pendidikan Kota Yogyakarta Nomor: 188/ 014. Persiapan penyelenggaraan latihan UN Mata Pelajaran Bahasa Inggris yang di- adakan Dinas Pendidikan Kota Yogyakarta meliputi pembentukan panitia pelaksana kegiatan latihan UN SMA kota Yogyakarta. Berdasarkan surat keputusan tersebut disusun pedoman penyelenggaraan latihan UN sesuai dengan kondisi yang ada di kota Yogyakarta.

Penyelenggaraan latihan UN dilaksanakan oleh panitia yang telah dibentuk oleh Dinas Pendidikan Kota Yogyakarta dengan mewakili masing-masing sekolah, panitia penyelenggara latihan soal UN menggunakan pedoman yang telah dipersiapkan oleh Dinas Pendidikan Kota Yogyakarta, agar penyelenggaraan latihan mempunyai konsep yang sama setiap sekolah, soal-soal yang diberikan masih relevan dengan materi yang dipelajari selama proses pembelajaran, dan pencapian SKL sama untuk semua sekolah, adapun kriteria dan kisi-kisi penyelenggaraan latihan UN.

Adanya pedoman yang sudah dijelaskan secara rinci maka dibuatlah pelaksanaan pengelolaan latihan UN Mata Pelajaran Bahasa Inggris yang meliputi: kepanitiaan, jadwal dan pengawasan. Pengawas latihan UN yang diselenggarakan Dinas pendidikan Kota Yogyakarta ini adalah guru senior. Calon guru pengawas diusulkan oleh kepala sekolah. Kriteria pengawas Latihan UN adalah guru yang tidak mengajar Mata Pelajaran Bahasa Inggris.

Berdasarkan hasil analisis yang dilakukan peneliti, Informasi mengenai input penyelenggaraan latihan UN Mata Pelajaran Bahasa Inggris diperoleh dari data wawancara terstruktur kepada kepala kurikulum Dinas Pendidikan Kota Yogyakarta, Waka Kurikulum masing-masing sekolah dan $\mathrm{Pa}-$ nitia penyusun soal latihan UN Mata Pelajaran Bahasa Inggris. Selain itu, diperoleh dari data pendukung yaitu data wawancara mendalam dan data observasi. Variable antecedent (input) terdiri dari komponen dukungan pemerintah. Berikut ini adalah deskripsi data untuk variabel input penyelenggaraan latihan ujian nasional Mata Pelajaran Bahasa Inggris yang dimulai dari data wawancara terstruktur dan dilanjutkan oleh data wawancara mendalam. 
Keberhasilan penyelenggaraan latihan UN Mata Pelajaran Bahasa Inggris bagi siswa SMA Swasta ex-RSBI di kota Yogyakarta memerlukan dukungan dari segala komponen pendidikan. Dukungan yang diperlukan berasal dari komponen antecedent (input), transaction (proses) dan outcomes (hasil) yang baik untuk menghasilkan komponen produk yang baik juga. Berdasarkan hasil evaluasi penyelenggaraan latihan UN Mata Pelajaran Bahasa Inggris SMA Swasta exRSBI di kota Yogyakarta, kualitas setiap komponen penyelenggaraan latihan UN Mata Pelajaran Bahasa Inggris berbeda antara sekolah satu dengan sekolah lainnya, namun ada juga yang sama pada variabel komponen tertentu. Lebih jelasnya, berikut ini pembahasan kualitas komponen penyelenggaraan latihan UN Mata Pelajaran Bahasa Inggris bagi siswa SMA Swasta exRSBI di kota Yogyakarta.

\section{Data Transaction (Proses)}

Berdasarkan data yang diambil dari data wawancara yang dilakukan oleh peneliti kepada Kepala kurikulum Dinas Pendidikan Kota Yogyakarta. Oleh karena soal Latihan UN merupakan dokumen yang termasuk rahasia karena penyelenggaran latihan UN ini juga dibuat menyerupai pelaksanaan UN yang sesungguhnya maka perlu diamankan dengan sebaik-baiknya. Namun ternyata, belum semuanya seperti yang diharapkan.

Sistem penyelenggaraan latihan UN dikonsep pelaksanaannya seperti pelaksanaan UN sebenarnya, sedangkan untuk alokasi waktu ditentukan oleh Dinas pendidikan Yogyakarta dengan berkoordinasi bersama pihak sekolah, agar pelaksanaanya sama untuk semua sekolah di SMA Yogyakarta, hal ini berjalan dengan baik karena adanya koordinasi dengan dinas pendidikan, sekolah dan panitia penyelenggara. Hasil penyelenggaraan latihan UN agar tidak subjektif atau agar tidak terjadi kecurangan saat ujian dilakukan pengawasan oleh guru intern, hasil ujian siswa dikumpulkan dikantor Dinas pendidikan, dan dikoreksi oleh team didinas pendidikan sesuai dengan skor penilaian dan rata-rata kelulusan untuk tahun ajaran $2013 / 2014$.
Alur pendistribusian soal latihan UN antara lain, tim pembuat soal latihan UN Mata Pelajaran Bahasa Inggris memberikan master soal kepada Dinas Pendidikan Kota Yogyakarta; pihak dinas yang sudah mendapatkan master soal lalu memberikan ke pihak penggandaan soal dalam hal ini adalah pihak percetakan; dari pihak percetakan kemudian, diserahkan ke subrayon yang sudah ditentukan pihak Dinas Pendidikan Kota Yogyakarta; dan subrayon memberikan soal-soal tersebut ke masing-masing sekolah sesuai subrayonnya.

Secara rinci pengamanan soal dilakukan dengan cara antara lain, sekolah mengambil soal langsung di Dinas Pendidikan Kota Yogyakarta; kepala sekolah mengamankan soal diruangan; saat latihan UN tiba soal dibagikan langsung kepada siswa dimasing masing kelas; selesai pelaksanaan latihan UN bahasa Inggris, jawaban siswa di kirim langsung ke Dinas Pendidikan Kota Yogyakarta; dan pihak dinas menyerahkan ke tim analisis jawaban siswa.

Secara fisik, pengamanan soal latihan UN ini dilakukan dengan baik. Namun, yang perlu menjadi perhatian adalah pengamanan secara substansi. Artinya, seorang penyusun soal, penggandaan soal atau siapapun yang terlibat dalam proses pembuatan soal yang melihat dan mengetahui soal latihan UN ini secara fisik tidak memberi buku soal kepada orang lain dan secara substansi tidak memberitahukan isi atau substansi soal itu kepada orang lain.

Pengamanan soal tidak hanya dilakukan oleh pihak Dinas saja melainkan sekolah juga ikut andil saat pengambilan dan pengiriman soal saat dikemblikan ke Dinas Pendidikan Kota Yogyakarta. Hal-hal yang dilakukan saat pengambilan soal adalah mengambil soal pada hari latihan UN, pengambilan soal didampingi oleh petugas keamanan. Setelah sampai disekolah soal disimpan oleh kepala sekolah sampai waktu ujian tiba. Dengan demikian, sebagai penanggung jawab keamanan soal di sekolah adalah kepala sekolah, termasuk didalamnya saat ujian berlangsung. Setelah soal selesai digunakan, soal tersebut diberikan kekantor 
Dinas pendidikan Kota Yogyakarta dan disimpan di sana. Demikian pula lembar jawaban siswa. Selanjutnya, sesuai dengan jadwal yang telah ditentukan, lembar jawaban siswa dikoreksi oleh panitia yang sudah ditunjuk oleh pihak Dinas Pendidikan Kota Yogyakarta. Lembar jawaban yang telah selesai dikoreksi akan disimpan oleh pihak dinas.

Lembar jawaban siswa dimasukkan ke dalam amplop dan ditutup rapat sesaat setelah latihan ujian dilaksanakan. Setelah seluruh lembar jawaban siswa terkumpul, pada hari itu juga dibawa kedinas dan diserahkan kepada panitia penyelenggara latihan UN. Lebih lanjut dapat dilihat secara rinci persepsi siswa tentang penyelenggaraan latihan ujian nasional Mata Pelajaran Bahasa Inggris pada tabel berikut.

Tabel 1. Persepsi Siswa tentang Penyelenggaran Latihan Ujian Nasional Mata Pelajaran Bahasa Inggris

\begin{tabular}{cccccccccc}
\hline & \multicolumn{8}{c}{ Penyelenggaraan Latihan Ujian Nasional } \\
\cline { 2 - 9 } Kategori & $\begin{array}{c}\text { Kualitas } \\
\text { Latihan } \\
\text { UN }\end{array}$ & $\begin{array}{c}\text { Manfaat } \\
\text { Latihan } \\
\text { UN }\end{array}$ & $\begin{array}{c}\text { Dampak } \\
\text { Latihan } \\
\text { UN }\end{array}$ & Total \\
\cline { 2 - 10 } & F & $\%$ & F & $\%$ & F & $\%$ & F & $\%$ \\
\hline Baik sekali & 27 & 10 & 28 & 11 & 17 & 7 & 12 & 5 \\
Baik & 93 & 36 & 83 & 32 & 90 & 35 & 92 & 36 \\
Cukup & 80 & 31 & 94 & 36 & 97 & 38 & 82 & 32 \\
Kurang baik & 48 & 19 & 35 & 14 & 41 & 16 & 54 & 21 \\
Sangat kurang & 10 & 4 & 18 & 7 & 13 & 5 & 18 & 7 \\
baik & & & & & & & & \\
\hline Total & 258 & 100 & 258 & 100 & 258 & 100 & 258 & 100 \\
\hline
\end{tabular}

Tabel 1 menunjukkan penyelenggaraan latihan ujian nasional masing-masing komponen. Berikut ini disajikan secara rinci penyelenggaraan latihan ujian nasional Mata Pelajaran Bahasa Inggris dari masing-masing komponen sebagai berikut.

Kualitas Latihan UN Mata Pelajaran Bahasa Inggris

Berdasarkan Tabel 1 dapat diketahui penyelenggaraan latihan ujian nasional untuk kualitas latihan UN Mata Pelajaran
Bahasa Inggris yaitu sebesar 10\% kategori baik sekali, 36\% kualitas latihan UN Mata Pelajaran Bahasa Inggris kategori baik, 31\% kualitas latihan UN kategori cukup, 19\% kualitas latihan UN kategori kurang baik, dan 4\% kualitas latihan UN Mata Pelajaran Bahasa Inggris kategori sangat kurang baik.

Manfaat Latihan UN Mata Pelajaran Bahasa Inggris

Berdasarkan Tabel 1 dapat diketahui penyelenggaraan latihan ujian nasional untuk manfaat latihan UN Mata Pelajaran Bahasa Inggris yaitu sebesar 11\% kategori baik sekali, 32\% manfaat latihan UN Mata Pelajaran Bahasa Inggris kategori baik, 36\% manfaat latihan UN Mata Pelajaran Bahasa Inggris kategori cukup, 14\% manfaat latihan UN Mata Pelajaran Bahasa Inggris kategori kurang baik, dan 7\% manfaat latihan UN Mata Pelajaran Bahasa Inggris kategori sangat kurang baik.

Dampak Latihan UN Mata Pelajaran Bahasa Inggris

Berdasarkan Tabel 1 dapat diketahui pe-nyelenggaraan latihan ujian nasional untuk dampak latihan UN Mata Pelajaran Bahasa Inggris yaitu sebesar 7\% kategori baik sekali, 35\% dampak latihan UN Mata Pelajaran Bahasa Inggris kategori baik, 38\% dampak latihan UN Mata Pelajaran Bahasa Inggris kategori cukup, 16\% dampak latihan UN Mata Pelajaran Bahasa Inggris kategori kurang baik, dan 5\% dampak latihan UN Mata Pelajaran Bahasa Inggris kategori sangat kurang baik.

Adapun grafik penyelenggaraan latihan ujian nasional Mata Pelajaran Bahasa Inggris pada Gambar 1.

Pada aspek proses (transaction) secara fisik, pengamanan soal latihan UN ini dilakukan dengan baik. Namun, yang perlu menjadi perhatian adalah pengamanan secara substansi. Artinya, seorang penyusun soal, penggandaan soal atau siapapun yang terlibat dalam proses pembuatan soal yang melihat dan mengetahui soal latihan UN ini secara fisik tidak memberi buku soal kepada orang lain dan secara substansi tidak mem- 
beritahukan isi atau substansi soal itu kepada orang lain.

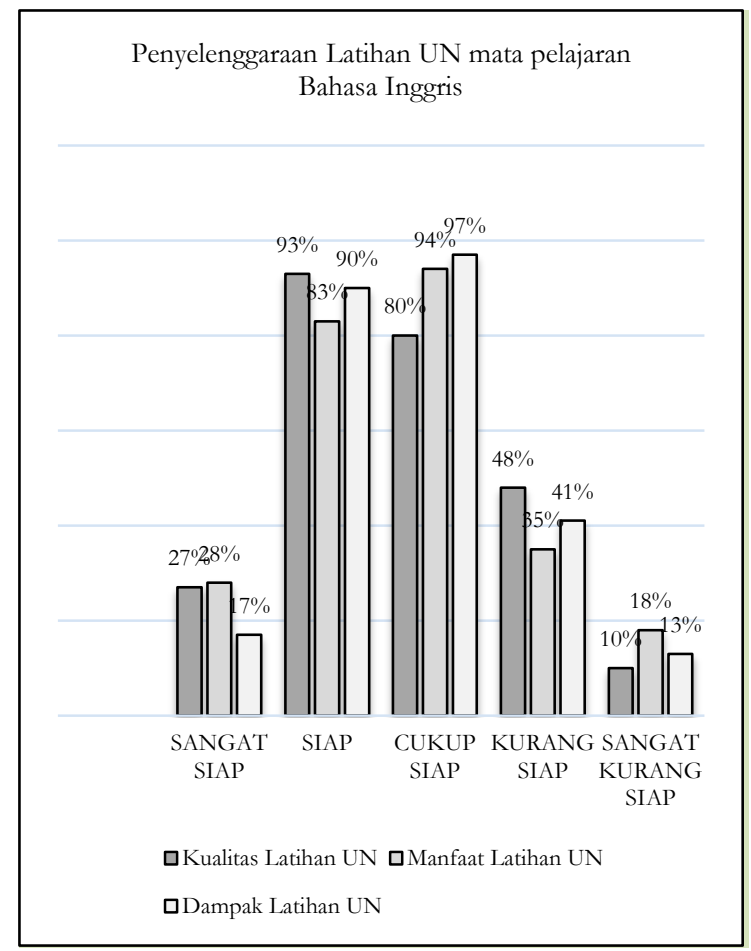

Gambar 1. Penyelenggaraan Latihan Ujian Nasional Mata Pelajaran Bahasa Inggris

Pengamanan soal tidak hanya dilakukan oleh pihak Dinas saja melainkan sekolah juga ikut andil saat pengambilan dan pengiriman soal saat dikemblikan ke Dinas Pendidikan Kota Yogyakarta. Hal-hal yang dilakukan saat pengambilan soal adalah mengambil soal pada hari latihan UN, pengambilan soal didampingi oleh petugas keamanan. Setelah sampai disekolah soal disimpan oleh kepala sekolah sampai waktu ujian tiba. Dengan demikian, sebagai penanggung jawab keamanan soal di sekolah adalah kepala sekolah, termasuk didalamnya saat ujian berlangsung. Setelah soal selesai digunakan, soal tersebut diberikan kekantor Dinas pendidikan Kota Yogyakarta dan disimpan disana. Demikian pula lembar jawaban siswa. Selanjutnya, sesuai dengan jadwal yang telah ditentukan, lembar jawaban siswa dikoreksi oleh panitia yang sudah ditunjuk oleh pihak Dinas Pendidikan Kota Yogyakarta. Lembar jawaban yang telah selesai dikoreksi akan disimpan oleh pihak dinas.
Penyelenggaraan latihan UN Mata Pelajaran Bahasa Inggris secara umum termasuk kategori baik, beberapa hal penting yang harus diperhatikan panitia penyelenggara latihan UN Mata Pelajaran Bahasa Inggris, yaitu: panitia penyelenggara latihan UN Mata Pelajaran Bahasa Inggris harus memperhatikan, menumbuhkan dan mempersiapkan mental siswa untuk pelaksanaan UN Mata Pelajaran Bahasa Inggris sesungguhnya, sehingga siswa benar-benar siap untuk pelaksanaan UN Mata Pelajaran Bahasa Inggris baik dari kemampuan akademik maupun dari kesiapan mental.

Manfaat penyelenggaraan latihan UN Mata Pelajaran Bahasa Inggris secara umum termasuk kategori cukup, dalam hal ini panitia penyelenggara harus menumbuhkan sikap percaya diri siswa untuk pelaksanaan latihan UN Mata Pelajaran Bahasa Inggris, oleh karena itu dengan adanya latihan UN Mata Pelajaran Bahasa Inggris yang baik bisa membangkitkan motivasi siswa untuk belajar lebih baik, sehingga siswa belum yakin atas kemampuanya untuk menjawab pertanyaan soal-soal latihan UN Mata Pelajaran Bahasa Inggris dan memperoleh nilai yang memuaskan sesuai dengan apa yang dipelajari selama proses pembelajaran.

Dampak penyelenggaraan latihan UN Mata Pelajaran Bahasa Inggris belum optimal memberikan solusi kepada siswa untuk siap melaksanakan UN Mata Pelajaran Bahasa Inggris. Sebaliknya, siswa menjadi tidak bisa konsentrasi untuk belajar karena memikirkan pelaksanaan latihan ujian nasional dan siswa menjadi cemas dengan kemampuanya untuk mengikuti UN Mata Pelajaran Bahasa Inggris, karena hasil yang diperoleh dalam penyelenggaran latihan UN Mata Pelajaran Bahasa Inggris tidak seluruh siswa mencapai target yng telah ditetapkan.

Data Outcomes (Hasil)

\section{Analisis Butir Soal}

Pada aspek hasil (outcome) dilakukan analisis kualitas perangkat tes latihan UN Mata Pelajaran Bahasa Inggris tahun 2013/ 2014 di kota Yogyakarta. Hasil analisis kualitas butir soal latihan ujian nasional Mata 
Pelajaran Bahasa Inggris SMA kelas XII diketahui bahwa reliabilitas tes sudah reliabel. Hal ini dibuktikan dengan nilai reliabilitas yang diperoleh sebesar 0,851. Nilai ini termasuk dalam kategori tinggi, sehingga dapat disimpulkan bahwa perangkat tes yang digunakan sudah reliabel. Kaitannya dengan dunia pendidikan, prestasi atau kemampuan seorang siswa dikatakan reliabel jika dilakukan pengukuran maka pengukuran yang dihasilkan akan memberikan informasi yang sama.

Kualitas butir soal pada teori tes klasik dilihat berdasarkan nilai tingkat kesukaran butir, daya beda dan keberfungsian distraktor. Hasil analisis menunjukkan bahwa secara keseluruhan diperoleh rerata tingkat kesukaran semua item sebesar 0,625 artinya tes ini rata-rata dijawab benar oleh $62,5 \%$ siswa. Nilai rerata tingkat kesukaran yang diperoleh mendekati ketegori ideal. Hal ini di dukung dari pendapat Lord (1952) dalam Anastasi dan Urbina (1997: 174) mengungkapkan bahwa untuk 5 alternatif jawaban soal pilihan ganda, rerata dari tingkat kesulitan butir yang ideal yaitu mendekati 0,67.

Analisis butir soal latihan UN Mata Pelajaran Bahasa Inggris berdasarkan teori tes klasik dapat dilakukan dengan bantuan software statistik yaitu MicroCAT Itemen. "Prop. Correct" pada output itemen menunjukkan tingkat kesukaran butir. "Biser" adalah indeks daya pembeda soal dengan menggunakan koefisien korelasi biserial. Sementara itu, "Prop. Endorsing" digunakan untuk melihat keberfungsian pengecoh. Sebelum dilakukan analisis perbutir, dilakukan analisis instrumen tes secara keseluruhan terlebih dahulu. Hasil analisisnya disajikan pada Tabel 2.

Pada Tabel 2 diketahui rerata tingkat kesukaran semua item sebesar 0,625 artinya tes ini rata-rata dijawab benar oleh $62,5 \%$ siswa. Ditinjau dari daya beda semua item, diperoleh rerta daya beda sebesar 0,341 yang termasuk dalam kategori baik. Nilai alpha sebesar 0,851 menunjukkan paket tes ini memiliki reliabilitas yang baik.
Kesalahan baku pengukuran menurut teori tes klasik dinyatakan dengan kesalahan baku pengukuran (Standar Error of Measurement/SEM). Besarnya SEM yang diperoleh yaitu 2,861. Besarnya SEM tergantung pada indeks kehandalan tes. Semakin kecil nilai SEM, maka tes tersebut semakin dapat diandalkan atau reliabel.

Tabel 2. Hasil Analsis Instrumen Tes Secara Keseluruhan Berdasarkan Teori Tes Klasik

\begin{tabular}{lr}
\hline \multicolumn{1}{c}{ Kriteria } & Hasil \\
\hline Jumlah item & 50 \\
Jumlah peserta tes & 214 \\
Skor rata-rata & 31,324 \\
Varians & 55,067 \\
Standar deviasi & 7,421 \\
Kemiringan distribusi skor & $-0,241$ \\
Puncak distribusi skor & $-0,436$ \\
Skor terendah & 36 \\
Skor tertinggi & 0,851 \\
Median & 2,861 \\
Koefisisen reliabilitas & 0,625 \\
Kesalahan pengukuran (SEM) & 0,341 \\
Rata-rata tingkat kesukaran & 0,480 \\
Rata-rata daya beda semua item & \\
Rata-rata daya beda korelasi biserial &
\end{tabular}

Hasil analisis butir tes ditinjau dari tingkat kesukaran, daya beda, serta efektifitas distraktor pada program MicroCat ITEMAN disajikan pad Tabel 3.

Ditinjau dari daya beda semua item, diperoleh rerata daya beda sebesar 0,341 yang termasuk dalam kategori baik. Hal ini berarti bahwa perangkat tes yang digunakan mampu membedakan antara siswa dengan kemampuan tinggi dan rendah. Mardapi (2008, p.143) mengungkapkan bahwa butir soal yang mampu membedakan siswa berkemampuan tinggi dengan siswa berkemampuan rendah adalah butir soal yang memiliki daya beda minimal 0,30. Namun demikian, terdapat beberapa butir soal yang memiliki daya beda negative yaitu butir soal nomor 2, 14, dan 26. Hal ini menunjukkan bahwa pada ketiga butir tersebut tidak dapat membedakan antara siswa berkemampuan tinggi dan rendah karena siswa yang ber- 
kemampuan tinggi menjawab salah dan siswa berkemampuan rendah menjawab benar (Mardapi, 2012, p. 128).

Tabel 3. Hasil Analsis Butir Soal Berdasarkan Teori Tes Klasik

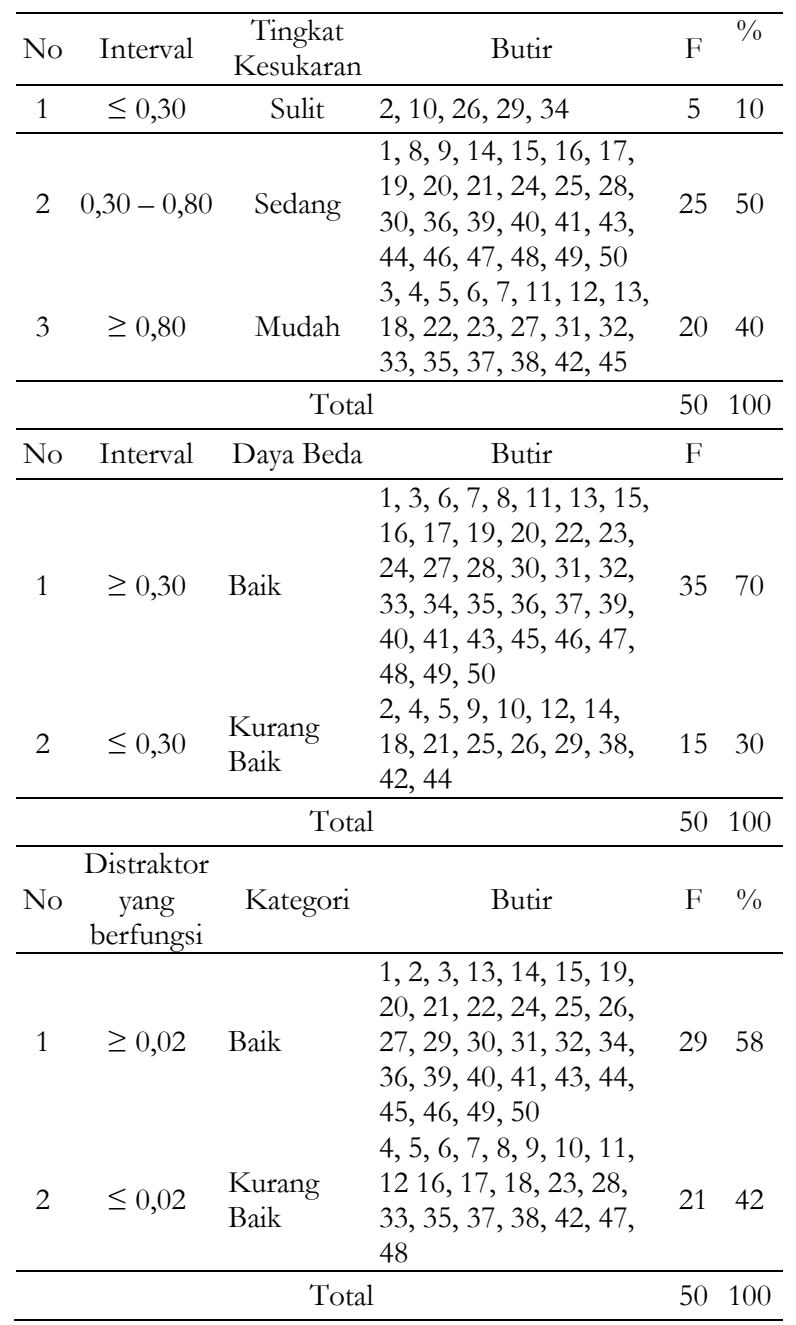

Analisis masing-masing butir dengan menggunakan teori tes klasik menunjukkan bahwa sebagian besar tingkat kesukaran butir termasuk kategori sedang yaitu 50\% dan daya beda $70 \%$ sangat baik. Keberfungsian distraktor sebagian besar berfungsi dengan baik 58\%. Hal ini berarti bahwa soal latihan ujian nasional Mata Pelajaran Bahasa Inggris SMA kelas XII cenderung lebih mudah bila dikerjakan oleh siswa.

Jika dilihat berdasarkan keputusan terhadap butir, menunjukkan bahwa sebagian besar butir ditolak $60 \%$, sedangkan butir yang diterima sebanyak $28 \%$ dan yang direvisi $12 \%$. Butir yang diterima bisa lang- sung masuk dalam bank soal sedangkan yang termasuk direvisi, maka butir-butir tersebut direvisi terlebih dahulu sebelum masuk bank soal.

Berdasarkan Tabel 3 diketahui bahwa berdasarkan tingkat kesukaran butir, sebagian besar tingkat kesukaran butir termasuk kategori sedang 50\%. Kategori mudah 20 butir 40\% dan kategori sulit hanya 5 butir $10 \%$. Berbeda dengan tingkat kesukaran butir, daya beda $\left(a_{i}\right)$ sebagian besar termasuk sangat baik $70 \%$, sedangkan yang tidak baik hanya 30\%. Hal ini menunjukkan bahwa perangkat tes tersebut mampu membedakan peserta tes dengan kemampuan tinggi dan rendah. Namun, terdapat soal yang memiliki daya beda negative yaitu butir 2, 14 dan 24 . Dilihat dari ketiga butir tersebut berarti siswa yang memiliki kemampuan tinggi banyak yang menjawab salah sedangkan siswa yang memiliki kemampuan rendah banyak menjawab benar yang benar pada ketiga butir tersebut. Ditinjau berdasarkan keberfungsian distraktor, sebagian besar distraktor berfungsi dengan baik 58\%.

Berdasarkan hasil analisis diatas maka dapat disimpulkan bahwa butir soal yang diterima sebesar $28 \%$, butir soal direvisi sebesar $12 \%$ dan butir soal yang ditolak sebesar $60 \%$. Butir-butir yang diterima selanjutnya bisa dimasukkan ke dalam bank Soal latihan ujian nasional bahasa Inggris SMA kelas XII. Butir yang dengan keputusan "direvisi" maka perlu dilakukan revisi terlebih dahulu sebelum masuk dalam bank soal. Untuk lebih jelasnya dapat dilihat pada Tabel 4.

Tabel 4. Ringkasan Analisis Keputusan Butir Soal dengan Teori Tes Klasik

\begin{tabular}{|c|c|c|c|}
\hline $\begin{array}{c}\text { Keputusan } \\
\text { terhadap } \\
\text { Butir }\end{array}$ & Butir & $\mathrm{F}$ & $(\%)$ \\
\hline Diterima & $\begin{array}{l}1,15,19,20,24,30,36,39 \\
40,41,43,46,49,50\end{array}$ & 14 & 28 \\
\hline Direvisi & $8,16,17,28,47,48$ & 6 & 12 \\
\hline Ditolak & $\begin{array}{l}2,3,4,5,6,7,9,10,11,12, \\
13,14,18,21,22,23,25,26, \\
27,29,31,32,33,34,35,37, \\
38,42,44,45\end{array}$ & 30 & 60 \\
\hline & Total & 50 & 100 \\
\hline
\end{tabular}




\section{Manfaat Latihan Ujian Nasional}

Hasil penyelenggaraan latihan UN sangat membantu untuk Dinas pendidikan Yogyakarta, sekolah, guru, siswa dan orang tua. Penyelenggaraan latihan UN untuk dinas pendidikan Yogyakarta membantu mengetahui peta kemampuan setiap sekolah, penyelenggaran latihan UN untuk sekolah bisa mengetahui pemahaman dan persiapan siswa dalam menghadapi UN.

Manfaat latihan UN bagi Dinas Pendidikan Kota Yogyakarta adalah sebagai bahan penilaian untuk menimbang kebijakan dan untuk alat ukur capaian materi proses belajar siswa, penting untuk persiapan UN. Penyelenggaraan latihan UN untuk membantu guru mengetahui kemampuan dan penguasaan siswa terhadap materi yang telah dipelajari, sehingga nantinya guru memberikan materi-materi tambahan yang kurang dikuasi oleh siswa. Penyelenggaran latihan UN untuk siswa melatih dan mempersiapkan siswa untuk pelaksanaan UN, dan untuk orang tua dapat mengurangi kegelisan dan mengontrol anaknya dalam mempersiapkan mengahadapi UN. Berdasarkan dari beberapa manfaat-manfaat yang telah dipaparkan adapun manfaat lainnya yaitu dalam hal kualitas soal latihan ujian nasional Mata pelajaran Bahasa Inggris dimana tim pembuat soal dapat mengetahui sudah seberapa baik soal yang telah dibuat.

\section{Simpulan dan Saran}

Berdasarkan hasil analisis dan pembahasan yang diuraikan pada bab-bab sebelumnya dapat disimpulkan sebagai berikut.

\section{Antecedent}

Persiapan yang dilakukan Dinas Pendidikan Kota Yogyakarta dan Persiapan sekolah dalam penyelenggaraan latihan UN Mata Pelajaran Bahasa Inggris SMA Swasta ex-RSBI dalam menghadapi Ujian Nasional di kota Yogyakarta termasuk sudah baik karena sesuai dengan surat keputusan yang dibuat oleh Dinas Pendidikan Kota Yogyakarta.

\section{Transaction}

Proses penyelenggaraan latihan UN Mata Pelajaran Bahasa Inggris SMA Swasta ex-RSBI dalam menghadapi Ujian Nasional di kota Yogyakarta sudah baik dan untuk manfaat latihan UN dan dampak latihan UN cukup baik. Dalam hal ini karena tingkat kesiapan siswa setelah mengikuti latihan UN Mata Pelajaran Bahasa Inggris SMA Swasta ex-RSBI dalam menghadapi Ujian Nasional di kota Yogyakarta. Siswa belum cukup siap untuk mengikuti latihan UN, penyelenggaraan latihan UN kurang mampu mempersiapkan mental, motivasi siswa, jadi siswa menjadi kurang percaya diri juga cemas dalam menghadapi penyelenggaraan latihan UN.

\section{Outcome}

Didalam outcomes hasil analisis kualitas butir soal latihan ujian nasional Mata Pelajaran Bahasa Inggris SMA kelas XII sudah reliabel $(0,851)$. Berdasarkan tingkat kesukaran termasuk dalam kategori sedang $(50 \%)$, daya beda dalam kategori baik $(70 \%)$ dan distraktor yang berfungsi termasuk dalam kategori baik (58\%). Manfaat penyelenggaraan latihan UN Mata Pelajaran Bahasa Inggris secara umum termasuk kategori cukup, dalam hal ini panitia penyelenggara harus menumbuhkan sikap percaya diri siswa untuk pelaksanaan latihan UN. Oleh karena itu, latihan UN yang baik bisa membangkitkan motivasi siswa untuk belajar lebih baik. Secara keseluruhan tidak terdapat hambatan-hambatan dalam penyelenggaraan latihan UN Mata Pelajaran Bahasa Inggris SMA Swasta ex-RSBI dalam menghadapi Ujian Nasional karena sudah sesuai dengan acuan yang telah dibuat oleh Dinas Pen-didikan Kota Yogyakarta.

Berdasarkan pembahasan dan kesimpulan maka penelitian ini menyarankan halhal seperti berikut ini. Bagi Dinas Pendidikan Kota Yogyakarta, meneruskan penyelenggaraan latihan ujian nasional Mata Pelajaran Bahasa Inggris dengan sedikit penyempuraan dalam hal pemanfaatan hasil latihan ujian nasional, melakukan standar- 
disasi mutu soal latihan ujian nasional Mata Pelajaran Bahasa Inggris, agar kualitas soal dari tahun ke tahun sama, supaya dapat diketahui secara jelas perkembangan kualitas pendidikan. Agar penyelenggaraan latihan ujian nasional Mata Pelajaran Bahasa Inggris berjalan lancar, perlu sosialisasi seawal dan sejelas mungkin tentang infomasi latihan ujian nasional yang meliputi: kisi-kisi soal latihan, bentuk soal latihan ujian, proses penskoran, aturan konversi skor/nilai, dan kriteria kelulusan, penyelenggaraan latihan ujian nasional Mata Pelajaran Bahasa Inggris sebaiknya dilaksanakan tidak terlalu dekat waktunya dengan penyelenggaraan ujian nasional tingkat nasional.

Sekolah dapat melakukan analisis hasil latihan ujian nasional Mata Pelajaran Bahasa Inggris mulai dari mencari NEM rata-rata sampai pada analisis materi yang belum dikuasai oleh siswa. Guru bisa mengetahui apa kendala-kendala seperti materi pelajaran yang dihadapi siswa.

Peneliti selanjutnya dapat meneliti mengenai penyelenggaraan latihan ujian nasional tidak hanya Mata Pelajaran Bahasa Inggris, namun juga seluruh mata pelajaran yang di ujikan dalam ujian nasional dan mengambil sampel dengan cara yang berbeda dan bisa dilakukan perbandingan antara sekolah negeri dan swasta.

\section{Daftar Pustaka}

BSNP. (2013). Prosedur operasional (POS) ujian nasional (UN) sekolah menengah atas/ madrasab aliyah (SMA/MA) tabun pelajaran 2013/2014.

Depdiknas. (2003). Undang-undang nomor 20, Tahun 2003 (pasal 3). Tentang sistem pendidikan nasional. Jakarta: Lembar Negara.
Depdiknas. (2004). Undang-Undang Nomor 32 Tahun 2004. Tentang pemerintaban daerah. Jakarta: Lembar Negara.

Depdiknas. (2005). Peraturan pemerintah RI Tabun 2005, tentang standar nasional pendidikan. Jakarta: Lembar Negara.

Fernandes, H. J. X. (1984). Evaluation of educational programs. Jakarta: National educational planning, Evaluation and Curicculum Development.

Hoover, H., D. (2002). Some common misconceptions about tests and testing. Educational Measurement: Issues And Practice. Volume 22, number1. The University of Iowa. Iowa City, IA: Iowa Testing Programs.

Leighton. J. P., \& Gierl. M. M. (2011). The learning sciences in educational assessment. Cambridge, MA: Cambridge University Press.

Mardapi, D. (2008). Teknik penyusunan instrumen tes dan nontes. Yogyakarta: Mitra Cendikia Press.

Mardapi, D. (2012). Pengukuran, penilaian dan evaluasi pendidikan. Yogyakarta: Nuha Medika.

Reyes, Sharon Adelman \& Kleyn, Tatyana. (2010). Teaching in 2 languges. California: Corwin A SAGE Company.

Reynolds, C. R., Livingston, R. B., \& Wilson, V. (2010). Measurement and assessment in education. Upper Saddle River, New Jersey: Pearson Education, Inc.

Salkind, N.J. (2013). Test and measurement for people who hate test \& measurement. $2^{\text {nd }}$ edition. California: SAGE Publication, Inc.

Widoyoko. E., P. (2013). Evaluasi program pembelajaran. Yogyakarta: Pustaka Pelajar. 